\title{
Perineal hernia repair using polypropylene mesh in three female Jaffarabadi buffaloes - a short communication
}

\author{
Vineet Kumar ${ }^{1,2 *}$, Foram A. Asodiya ${ }^{2}$, Shruti D. Vora ${ }^{2}$, and Vivek K. Singh ${ }^{3}$ \\ ${ }^{1}$ Department of Veterinary Surgery and Radiology, College of Veterinary and Animal Sciences, Sardar Vallabhbhai \\ Patel University of Agriculture and Technology, Meerut, Uttar Pradesh, India \\ ${ }^{2}$ Department of Veterinary Surgery and Radiology, College of Veterinary Science and Animal Husbandry, Junagadh \\ Agricultural University, Junagadh, Gujarat, India \\ ${ }^{3}$ Department of Veterinary Physiology and Biochemistry, College of Veterinary Science and Animal Husbandry, \\ Junagadh Agricultural University, Junagadh, Gujarat, India
}

KUMAR, V., F. A. ASODIYA, S. D. VORA, V. K. SINGH: Perineal hernia repair using polypropylene mesh in three female Jaffarabadi buffaloes - a short communication. Vet. arhiv 91, 327-332, 2021.

\section{ABSTRACT}

This study reports a rare unilateral perineal hernia in three mature female Jaffarabadi buffaloes. The buffaloes presented with a unilateral swelling lateral to the vulvar lip. Upon palpation, the swelling was painless, soft and reducible. Ultrasonography revealed a hyperechoic hernia sac containing the urinary bladder and or motile intestine, with homogenous hypoechoic contents. The perineal hernia was repaired using polypropylene mesh after the repositioning of the retroflexed urinary bladder and/or large intestine. The clinical outcome, including postoperative complications and hernia recurrence, was found via periodic examination and telephone calls. No complications were observed for 6 months of follow-up and all the buffaloes had excellent outcomes.

Key words: buffalo; perineal hernia; polypropylene mesh

\section{Introduction}

Perineal hernia has been described as the failure of the supporting structures of the pelvic outlet that results in the inability of the pelvic diaphragm to contain the pelvic viscera (FERREIRA and DELGADO, 2003). It results in weakening of the pelvic diaphragm muscles (FERREIRA and DELGADO, 2003). Primary closure of the hernial defect exceeding $3 \mathrm{~cm}$ in diameter by conventional suturing techniques often results in failure (MATTHEWS et al., 2003). Hence, a prosthetic mesh is required to achieve the tension-free closure

of such a defect (VILAR et al., 2011). Perineal hernia is a common condition in mature intact male dogs (KUMAR et al., 2016; GILL and BARSTAD, 2018), but rare in buffaloes. Herein, we report rare unilateral perineal hernias in three mature female Jaffarabadi buffaloes, and their tension-free mesh repair.

\section{Material and methods}

Animals. Three mature female Jaffarabadi buffaloes with perineal swellings were included

\footnotetext{
*Corresponding author:

Vineet Kumar, BVSc\&AH, MVSc, PhD, Department of Veterinary Surgery and Radiology, College of Veterinary and Animal Sciences, Sardar Vallabhbhai Patel University of Agriculture and Technology, Meerut 250110, Uttar Pradesh, India, Phone: +91 930414 1435; E-mail: bharadwaj374@gmail.com
} 
in this study. The perineal swellings in buffalo \#1 (7-year-old, body weight $575 \mathrm{~kg})$, \#2 (6-year-old, body weight $500 \mathrm{~kg}$ ) and \#3 (7-year-old, body weight $525 \mathrm{~kg}$ ) were first noticed by the animals' owners on day 30,15 and 20 , respectively before presentation. The buffaloes had a history of recent calving, and difficult defecation and urination. At the time of presentation, all the buffaloes were in good health. Body temperature, respiration and heart rates were normal. Upon visual inspection of the perineal region, $23-\mathrm{cm}$ and $19-\mathrm{cm}$ swellings were noted lateral to the right vulvar lip in buffaloes \#1 (Fig. 1A) and \#2, respectively. In buffalo \#3 the swelling was $21-\mathrm{cm}$ in size and lateral to the left vulvar lip. The swellings were soft, painless and reducible in size by manual pressure. On rectal palpation, $11-\mathrm{cm}$ and 9-cm-length hernia openings were felt $3.5 \mathrm{~cm}$ lateral to the right vulvar lip, between the levator ani and coccygeus muscles, and the internal obturator and external anal sphincter muscles in buffaloes $\# 1$ and \#2, respectively. The hernial opening was $7-\mathrm{cm}$ in length and $3-\mathrm{cm}$ lateral to the left vulvar lip in buffalo \#3. A herniated loop of large intestine and retroflexed urinary bladder were felt through an opening in the pelvic diaphragm in buffaloes \#1 and \#3, whereas the bladder was retroflexed in buffalo \#2. Rectal diseases, such as rectal deviation, rectal sacculation, and rectal diverticulum were not found in any of the animals. Ultrasonography revealed a hyperechoic hernia sac containing the retroflexed urinary bladder and motile large intestine loop with homogenous hypoechoic contents in buffaloes \#1 and \#3, but only the bladder in buffalo \#2. On the basis of palpation and ultrasonographic findings, the swellings were diagnosed as unilateral perineal hernia. Due to entrapment of the urinary bladder, immediate open prosthetic repair was planned. All the owners granted written informed consent prior to hernioplasty.

Surgery and implantation. Preoperatively, an intramuscular injection of antibiotic $(10 \mathrm{mg} / \mathrm{kg}$ amoxicillin-sulbactam) and analgesic $(0.3 \mathrm{mg} /$ $\mathrm{kg}$ meloxicam) was administered. After fasting for 24 hours and deprived of water for 12 hours, the animals were sedated with an intravenous injection of $0.2 \mathrm{mg} / \mathrm{kg}$ diazepam. Further, $6 \mathrm{~mL} \mathrm{2 \%}$ lignocaine hydrochloride was injected epidurally into the sacrococcygeal space. The buffaloes were restrained in a standing position in a cattle crate, with their tails pulled and fixed over their backs. A lubricated gauze was inserted into the rectum, and a temporary purse-string suture was placed around the anus. The skin on the perineal area and base of the tail was liberally clipped, aseptically prepped with chlorhexidine and alcohol, and routinely draped.

A dorso-ventral $15-\mathrm{cm}$ linear skin incision was made over the perineal hernia. The skin and underlying fascia were separated. The herniated organs, such as the bladder (Fig. 1B) and large intestine that were found to be free from adhesions were identified, and manually returned to their anatomic positions. Subsequently, the hernia openings were identified between the levator ani and coccygeus muscles, and the internal obturator, and external anal sphincter muscles (Fig. 1C). To bridge the hernia opening in each animal, an appropriately sized polypropylene mesh (Dolphin, Futura Surgicare Pvt. Ltd., Bangalore, India) was anchored to the external anal sphincter medially, the levator ani and coccygeus muscles dorso-laterally, and the internal obturator muscle ventrally, with a single interrupted suture of \#2 nylon material (Fig. 1D). Sutures were placed $1.5 \mathrm{~cm}$ apart. Supplementary simple continuous sutures were placed between the single interrupted sutures to keep the mesh under tension, to keep the pelvic and abdominal viscera reduced, and to support the rectal wall. Lastly, the mesh was covered by fasciae diaphragmatis pelvis interna and externa, and subcutaneous tissue. The skin incision was apposed using \#2 nylon in a horizontal mattress suture pattern. The purse-string suture and the gauze plug were removed.

Postoperatively, the surgical area was covered with a sterile bandage to protect it from the external environment. The animals continued on antibiotics (amoxicillin-sulbactam combination $10 \mathrm{mg} / \mathrm{kg}$ once a day intramuscularly) for five days and analgesic (meloxicam $0.3 \mathrm{mg} / \mathrm{kg}$ once a day intramuscularly) for three days. The bandage was replaced daily for 10 days, at which time the suture line was dressed with $0.1 \%$ povidone iodine solution. Sutures were removed 10 days after surgery, when the cutaneous wound showed normal healing. To avoid post- 

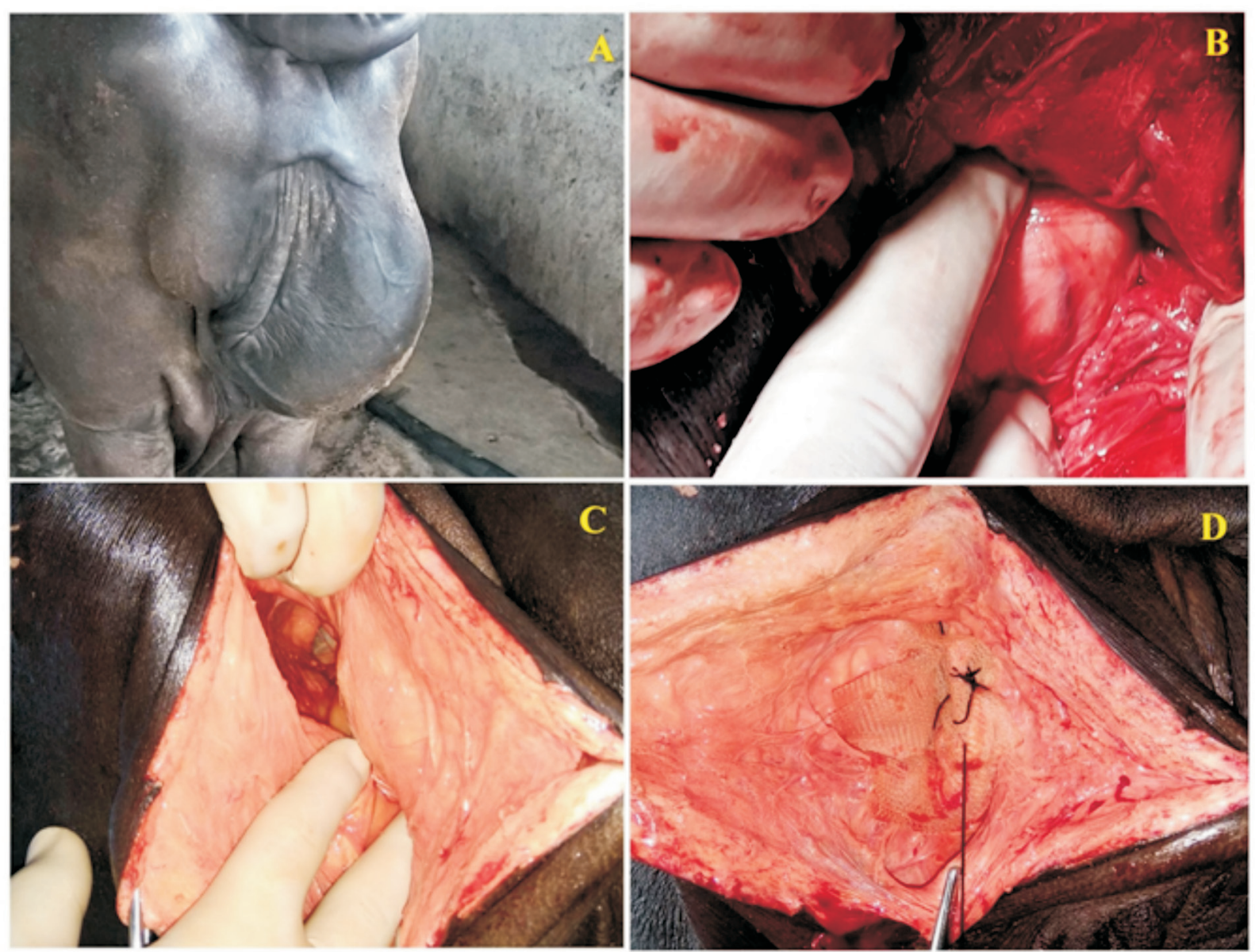

Fig. 1. The preoperative appearance of the perineal hernia in buffalo \#1 (A), an intraoperative image showing retroflexed urinary bladder in buffalo \#2 (B), intraoperative image showing hernia opening in buffalo \#3 (C), intraoperative image showing repair of perineal diaphragm defect with polypropylene mesh (D).

operative straining during defecation, the owners were instructed to keep the buffaloes on grass fodder for 30 days. Evaluation was carried out on the basis of the following parameters.

Clinical evaluation. Body temperature, and respiratory and heart rates were recorded before and on post-operative days 7 and 15. Follow-up was by periodic examinations and telephone calls every week for 1 month, and then every 4 weeks for a minimum of 6 months. Local complications, urination and defecation were observed. Tenesmus was subjectively assessed by the buffalo owners. No recurrence, and the comfort of the animals in relation to urination and defecation were determined as the success of the perineal hernioplasty with the polypropylene mesh.
Hematological evaluation. Complete blood count and erythrocyte sedimentation rate (ESR) were performed in triplicate before and on postoperative day 7 and 15 . Hematological parameters, such as hemoglobin $(\mathrm{Hb})$, packed cell volume (PCV), total erythrocyte count (TEC), mean corpuscular volume (MCV), mean corpuscular hemoglobin $(\mathrm{MCH})$, mean corpuscular hemoglobin concentration $(M C H C)$, total leukocyte count, differential leukocyte count and platelet count were estimated using an automated hematology analyzer. ESR was estimated manually using Wintrobe's method.

Biochemical evaluation. Serum biochemical parameters were estimated in triplicate before and on post-operative day 7 and 15 . Total protein 
(TP), albumin, glucose, aspartate aminotransferase (AST), alanine aminotransferase (ALT), lactate dehydrogenase (LDH), alkaline phosphatase (ALP), creatine kinase (CK), creatinine, cholesterol, triglyceride, high-density lipoprotein (HDL), low-density lipoprotein (LDL), urea, urea nitrogen, and gamma-glutamyl transferase (GGT) levels were measured by standard absorptive spectrophotometric methods using commercial test kits, with an automatic serum biochemical analyzer. Albumin-globulin ratio (A:G) was calculated mathematically from the estimated serum albumin and total protein contents.

Antioxidants evaluation. Erythrocytic antioxidants were estimated before and on post-operative days 7 and 15. One milliliter of erythrocytic haemolysate was prepared from 20 $\mu \mathrm{L}$ of heparinized blood by adding $980 \mu \mathrm{L}$ of $1 \mathrm{X}$ RBC lysis buffer. Reduced glutathione (GSH) concentration in erythrocytic hemolysate was determined using the published method (ELLMAN, 1959). Catalase activity in erythrocytic hemolysate was estimated spectrophotometrically using a double beam UV spectrophotometer at a wavelength of $240 \mathrm{~nm}$ after the appropriate dilution, as described by AEBI (1984). Decomposition of $\mathrm{H}_{2} \mathrm{O}_{2}$ was followed directly by a decrease in absorbance per minute, and this was taken as a measure of the catalase activity.

Statistical analysis. Data were analyzed by one way analysis of variance. Results were expressed as the mean \pm standard error (SE) of the mean. The pair-wise comparison of means was carried out using Tukey's multiple range test. A difference with a value of $\mathrm{P}<0.05$ was considered statistically significant.

\section{Results and discussion}

Perineal hernia is uncommon in buffaloes and, in contrast to dogs, the condition is exclusively reported in female animals (PRASAD et al., 2015; VADALIA et al., 2017), possibly associated with estrogen and relaxin hormones. Studies have shown that the highest production of relaxin occurs in the female reproductive organs during pregnancy, with the corpus luteum, deciduas, and placenta being the primary sources. Other, less prominent sources of relaxin include the endometrial glands, thecal cells, and mammary gland parenchymal cells (BANI, 1997; SHERWOOD, 2004). A study also found an increased expression of relaxin receptors within the muscles of the pelvic diaphragm in dogs with perineal hernias (MERCHAV et al., 2005). In this regard, the low incidence of perineal hernia in female dogs could be attributed to the greater strength, size and area of rectal attachment of the levator ani muscles (HEDLUND, 2012). Neurogenic atrophy of the levator ani or coccygeus muscles is another underlying cause of perineal hernia in dogs; however, this etiology can be ruled out in the present study due to no known history of trauma.

Surgical reconstruction of the pelvic diaphragm is usually recommended for perineal hernia repair. A number of surgical techniques, including the use of implants (polypropylene mesh, acellular dermal matrix) have been described to treat perineal hernia in dogs (KUMAR et al., 2016; VILLAMIL and CARRERA, 2016). Frequent complications observed in dogs after perineal hernia repair include wound infection and dehiscence, persistence of clinical signs, such as tenesmus and fecal incontinence, rectal prolapse, urinary tract dysfunction, sciatic paralysis and hernia recurrence (HOSGOOD et al., 1995; HEDLUND, 2012). These complications were not reported in the present study for 6 months of available followup. Presenting clinical signs were resolved a week after surgery, and all the buffaloes had excellent outcomes. Body temperature, and respiratory and heart rates did not change significantly $(\mathrm{P}>0.05)$ on days 7 and 15 as compared to their respective day 0 values. Mild inflammatory edemas were observed during the first 2 days after surgery. They gradually decreased on day 7. On day 10, incision site healing was normal, with healthy epithelization.

Hemoglobin, PCV, TEC, MCV, MCH, MCHC, TLC, lymphocytes, monocytes, basophils, eosinophils, and platelet count did not change significantly $(\mathrm{P}>0.05)$ on post-operative days 7 and 15 as compared to the pre-operative (day 0 ) values. Neutrophils and ESR were significantly $(\mathrm{P}<0.05)$ increased on post-operative day 7 as compared to the pre-operative (day 0) values. The increased 
neutrophils and ESR on post-operative day 7 may be due to the initial inflammatory response. Total protein, albumin, globulin, albumin-globulin ratio, glucose, creatinine, urea, urea nitrogen, cholesterol, triglyceride, HDL, LDL, ALP, LDH, CK, ALT, AST, and GGT levels did not changed significantly $(\mathrm{P}>0.05)$ on post-operative days 7 and 15 as compared to the pre-operative (day 0 ) values, indicating uncomplicated healing in the present study. Antioxidants, such as reduced glutathione (GSH) and catalase play a critical role in scavenging the reactive oxygen species that protect the body from oxidative damage (PREVILLE et al., 1999). In the present study, a nonsignificant $(\mathrm{P}>0.05)$ change was observed in the GSH levels and catalase activity in the animals at all intervals, indicating the absence of oxidative stress.

In conclusion, we have reported rare unilateral perineal hernias in mature female Jaffarabadi buffaloes, and successful repair using polypropylene mesh.

\section{Acknowledgement}

We would like to thank Junagadh Agricultural University for providing the facilities required for this study.

\section{References}

AEBI, H. (1984): Catalase in vitro. Methods Enzymol. 105, 121-126.

BANI, D. (1997): Relaxin: a pleiotropic hormone. Gen. Pharmac. 28, 13-22.

ELLMAN, G. L. (1959): Tissue sulfhydryl groups. Arch. Biochem. Biophys. 82, 70-77.

FERREIRA, F., E. DELGADO (2003): Hernias perineais nos pequenos animais. Revista Portuguesa de Ciencias Veterinarias 545, 3-9.

GILL, S. S., R. D. BARSTAD (2018): A review of the surgical management of perineal hernias in dogs. J. Am. Anim. Hosp. Assoc. 54, 179-187.

HEDLUND, C. S. (2012): Perineal hernia. In: Small Animal Surgery, $4^{\text {th }}$ ed. (Fossum, T. W., Ed.) Mosby, St. Louis. pp 568-573.
HOSGOOD, G., C. S. HEDLUND, R. D. PECHMAN, P. W. DEAN (1995): Perineal herniorrhaphy: perioperative data from 100 dogs. J. Am. Anim. Hosp. Assoc. 31, 331-342.

DOI: $10.5326 / 15473317-31-4-331$

KUMAR, V., A. K. GANGWAR, N. KUMAR (2016): Evaluation of the murine dermal matrix as a biological mesh in dogs. Proc. Natl. Acad. Sci. India Sect. B Bio.1 Sci. 86, 953-960.

DOI: $10.1007 / \mathrm{s} 40011-015-0543-8$

MATTHEWS, B. D., B. L. PRATT, H. S. POLLINGER, C. L. BACKUS, K. W. KERCHER, R. F. SING, B. T. HENIFORD (2003): Assessment of adhesion formation to intra-abdominal polypropylene mesh and polytetrafluoroethylene mesh. J. Surg. Res. 114, 126-132.

DOI: 10.1016/s0022-4804(03)00158-6

MERCHAV, R., Y. FEUERMANN, A. SHAMAY, E. RANEN, U. STEIN, D. E. JOHNSTON, R. SHAHAR (2005): Expression of relaxin receptor LRG7, canine relaxin, and relaxin-like factor in the pelvic diaphragm musculature of dogs with and without perineal hernia. Vet. Surg. 34, 476-481. DOI: 10.1111/j.1532-950x.2005.00072.x

PRASAD, V. D., B. C. PRASAD, G. KAMALAKAR, R. MAHESH (2015): Perineal hernia in a buffalo heifer: a case report. J. Vet. Sci. Tech. 4, 5-8.

PREVILLE, X., F. SALVEMINI, S. GIRAUD, S. CHAUFOUR, C. PAUL, G. STEPIEN, M. V. URSINI, A. P. ARRIGO (1999): Mammalian small stress proteins protect against oxidative stress through their ability to increase glucose-6phosphate dehydrogenase activity and by maintaining optimal cellular detoxifying machinery. Exp. Cell Res. 247, 61-78.

DOI: $10.1006 /$ excr.1998.4347

SHERWOOD, O. D. (2004): Relaxin's physiological roles and other diverse actions. Endocrine Rev. 25, 205-235.

DOI: 10.1210/er.2003-0013

VADALIA, J. V., V. KUMAR, V. D. DODIA, N. R. PADALIYA, K. S. GAMETI (2017): Surgical management of perineal hernia - a study in four Jafarabadi buffaloes. Intas Polivet $18,365-366$.

VILAR, J. M., J. A. CORBERA, G. SPINELLA (2011): Double-layer mesh hernioplasty for repairing umbilical hernias in 10 goats. Turk. J. Vet. Anim. Sci. 35, 131-35.

VILlAMIL, S. C., E. A. CARRERA (2016): Perineal herniorrhaphy in a dog using a cone-shaped polypropylene mesh implant. Vet. Rec. Case Rep. 4, e000298.

DOI: $10.1136 /$ vetreccr-2016-000298
Received: 1 March 2019

Accepted: 5 May 2021 
KUMAR, V., F. A. ASODIYA, S. D. VORA, V. K. SINGH: Liječenje perinealne hernije u tri ženke Jaffarabadi bivola primjenom polipropilenske mreže - kratki prikaz. Vet. arhiv 91, 327-332, 2021.

\section{SAŽETAK}

U tri ženke Jaffarabadi bivola prikazana je rijetka perinealna hernija s jednostranom oteklinom lateralno prema stidnim usnama. Na palpaciju je oteklina bila bezbolna, mekana i reverzibilna. Ultrazvučno je utvrđena hiperehoična hernijska vreća koja je sadržavala mokraćni mjehur i/ili pokretljiva crijeva s homogenim hipoehogenim sadržajem. Perinealna hernija liječena je upotrebom polipropilenske mreže nakon repozicije retrofleksiranog mokraćnog mjehura i/ili debelog crijeva. Klinički ishod, uključujući poslijeoperacijske komplikacije i ponovni nastanak hernije, praćen je redovitim pregledima i telefonskim pozivima. Tijekom šest mjeseci praćenja nisu uočene nikakve komplikacije i u svih je ženki ishod kirurškog liječenja bio izvrstan.

Ključne riječi: bivol; perinealna hernija; polipropilenska mreža 